\title{
Problem Based Learning with The SETS Method to Improve the Student's Critical Thinking Skill of Senior High School
}

\author{
${ }^{*}$ Devy Alvionita1, Prabowo², Z. A. Imam Supardi ${ }^{3}$ \\ 1,2,3 Postgraduate Program, State University of Surabaya, Indonesia
}

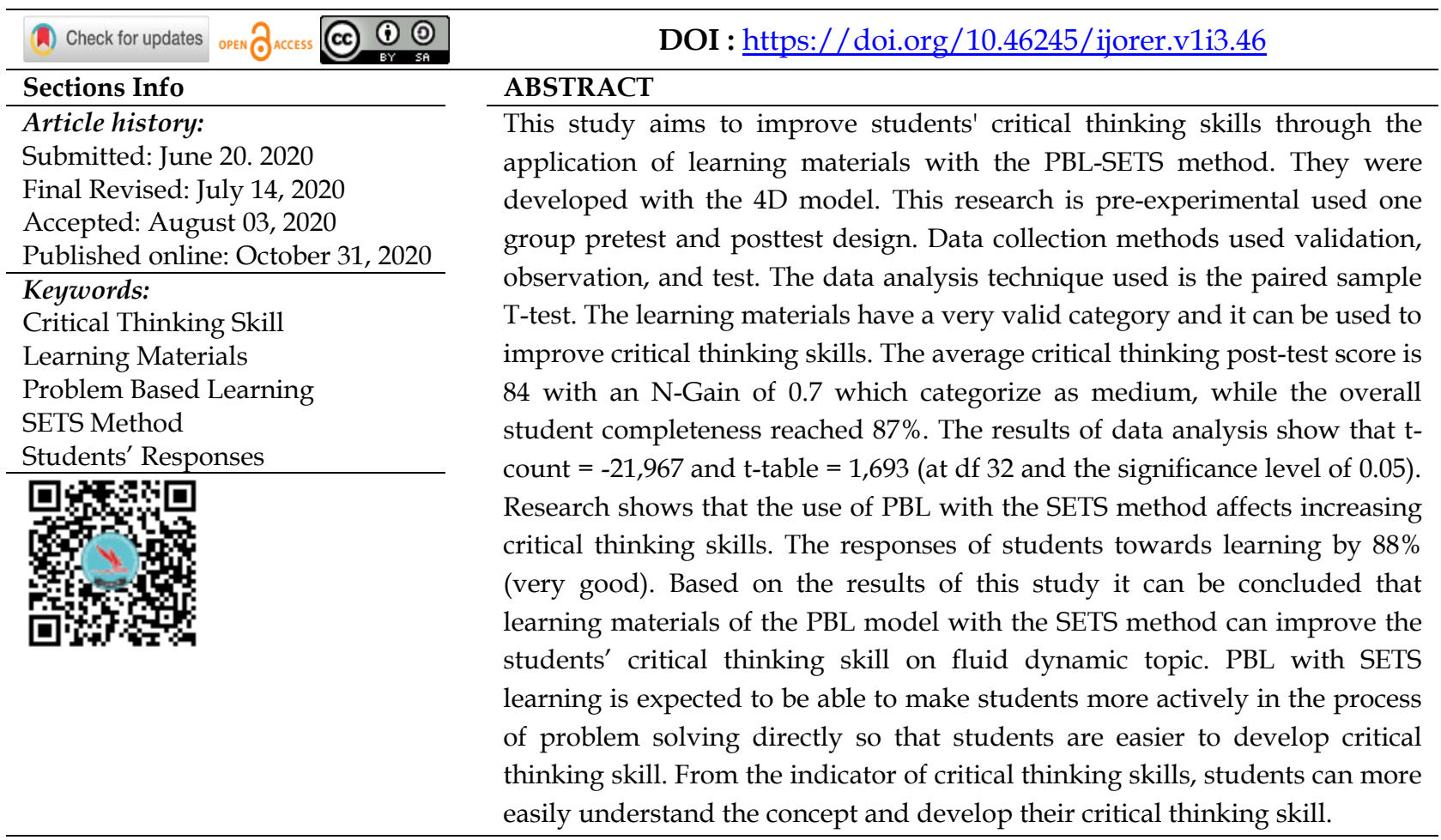

\section{INTRODUCTION}

Learning is a complex activity because in its implementation it is not only about conveying knowledge or messages to students, but it requires the interaction between students and teachers and interactions between students. Learning is a deliberate and purposeful effort that focuses on the interests, characteristics, and conditions so that students can learn effectively and efficiently (Thobroni, 2015). The implementation of learning activities includes components such as curriculum, media, and facilities used during the learning process. All learning components will be able to create effective learning if they can meet the principles of learning activities.

Determination of a good and appropriate learning process also needs to pay attention to the characteristics of the field of science itself, where Natural Sciences especially in the field of physics is a lesson that teaches reasoning and analysis so that almost all problems relating to nature can be understood. To be able to understand Natural Sciences, it must start with the skill to understand basic concepts in physics. The role of the teacher looks very important in facilitating students to gain knowledge and skills, one of which is critical thinking skills, so Students as stakeholders are directly involved with the problem, and challenged to learn to solve the problem (Belecina \& Ocampo, 2018). 
The students' skill to think critically is still lacking, because of the teacher's limited skill to develop, as is well known in physics is known as a lesson full of formulas that are considered difficult. Based on the problem of underdeveloped students' critical thinking skills above, it requires a learning process where students are active in exploring their knowledge, students can understand concepts and the skill to analyze properly and correctly to have good critical thinking skills. This case is important because critical thinking is now seen as an important skill that students must possess as part of the community and curriculum. The concept is emphasized as one of the $21^{\text {st }}$ century skills centers in education, society, and the world of work because, in this modern era, critical thinking strategy is one of the abilities to prepare students to live the rigors of life in the environment, and help them develop the skills needed to compete in the economic field in a global environment (Taylor, 2012).

Seeing the above problems, one of the alternative learning that can be used to overcome the above problems is by applying problem-based learning with the Science, Environment, Technology, and Society method. The SETS method in physics learning is expected to make students see things in an integrated way, by paying attention to the elements contained in SETS namely science, environment, technology, and society, so the teachers can connect the concepts of science taught with problems that occur in society, and the daily environment of students. The SETS method believes that learning physics presents a close relationship between students and the real world. The learning process will train students to identify problems well. A learning environment is created where students can collect data being found problem and solving by them self, consider alternative solutions, and can determine the best way to solve problems. The main reason for the SETS method is this learning-oriented towards the active participation of students. Students are guided to have the ability to think critically about environmental problems, technological developments, and actively solve problems. Using the SETS method can significantly enhance students' understanding of the nature of science and attitudes towards science compared to students who use traditional learning (Akcay, 2015).

The SETS method provides an understanding of the links between science, environment, technology, and society and a vehicle for training students' sensitivity to environmental impacts as a result of the development of science and technology (Poedjiadi, 2010). The SETS method can make Physics learning more meaningful because it is directly related to problems that arise in daily life, can increase the skill to apply concepts, process skills, creativity, and attitudes towards technology products, and take responsibility for problems that arise in the student environment.

Learning with the SETS method can help students to develop abilities in integrating elements of science, environment, technology, and society. This method can encourage students to study science as a whole, use science in the application of technology and study its impact on the environment and community development. SETS-based learning stages in Usmeldi (2017) namely (1) identifying problems involving science related to the environment, technology, and society; (2) formulating the problem; (3) theoretical reviews; (4) formulating a hypothesis; (5) collecting and analyzing data; and (6) interpret and conclude research results. so that problem-based learning and SETS are suitable models and methods when combined, because one way to develop creativity and critical thinking skills is to give students problems to be analyzed. 
The problem-based learning models with the SETS method can provide learning experiences for students in identifying potential problems, collecting data related to problems, considering alternative solutions, and considering the consequences based on certain decisions. The SETS method to learning is intended to find out, where Physics can produce technology for environmental improvement so that it benefits the community. They must be able to determine alternative solutions to analyze the influence of their values and the environment (Hove, 2011).

In this study critical thinking skills that will be measured by using critical thinking indicators according to indicators from Facione (2015) are not only because they are the latest indicators to measure critical thinking skills, indicators of Facione have been refined and reordered in order. The six indicators of critical thinking skills developed by Fascione are further divided into five types of skills according to Facione (2015) including interpretation, analysis, evaluation, inference, explanation.

\section{Research Focus}

In the previous research, research by Maimunah (2017) this study aims to find out the improvement of students' scientific attitudes and critical thinking skills on colloid concepts that can be improved by applying learning chemistry with SETS learning models. The results obtained from students' scientific attitudes were $72.7 \%$ (good category) and critical thinking skills of students with N-Gain in the medium category. The same thing was revealed by Priyadi, et al., (2018) that the low critical thinking skill in evaluating indicators was seen from students having difficulty when associating a concept with others and the learning habits of students tended to only receive information from the teacher alone. The learning applications consisting of SETS that support the application of science in science, environment, technology, and social including existing issues, students supporting SETS-based modules are feasible to be used in science learning. Based on the results of the t-test, there is a significant difference between the control class and the experimental class (0.004), with the control score and the experimental class respectively 0.270 (low) and 0.470 (moderate). That shows that modules based on SETS are more effective than textbooks. It can improve students' critical thinking skills and be appropriate for use in the learning process. This explains that if students know science or knowledge, it will have an impact on their lives, the environment, and developing technological adaptations. The research supports the development of SETS-based learning materials, where the four aspects of the SETS of methods are integrated in physics learning. Research conducted by Riwu et al. (2018) SETS-based learning can improve student learning outcomes, absorption, and completeness of classical learning students, this is because the learning that is done integrates the SETS elements in the material being studied.

However, in this study PBL learning models have been specifically designed to improve students' critical thinking skills for high school and integrated with the SETS method. In addition to the application of PBL, this study is complemented by the SETS method so that learning is accompanied by an integration of the four aspects of SETS, students are expected to develop their critical thinking skills. The PBL model consists of 6 phases, including 1) Orient students to the problem 2) Organize students for study 3) Assist independent and group investigations 4) Develop and present artifacts and exhibits) 5) Analyze and evaluate the problem-solving process and combined with aspects of SETS which include science, environment, technology, and social. The 
purpose of this study is to effect the PBL model with SETS to improve students' critical thinking skills.

\section{RESEARCH METHOD}

The main problem of this research is how to effectively apply problem-based learning (PBL) with the SETS method to improve the critical thinking skill of high school students in learning physics. Develop learning materials that are agreed to requirements if they meet valid and reliable requirements (content and construct). This research is categorized as $\mathrm{R} \& \mathrm{D}$ (research and development). The focus of this research is on the quality of the application of learning with developed with $4 \mathrm{D}$ model and validated by two experts (content validity and construct validity) from the development of PBL-based learning materials with the SETS method that can help increase educational motivation. The purpose of this study is to apply quality PBL with SETS method learning that can improve the critical thinking skills of high school students in dynamic fluid physics subject matter.

The research was tested in class XI-MIPA 2 at one of the High School in Gresik East Java with purposive sampling, by involving 33 students using the One Group Pre-Test Post-Test design model. The time of research implementation in the second semester of 2019/2020. Data collection methods used were validation, observation, and tests. The research data are processed descriptively.

\section{Analysis of Validation}

This study used PBL learning models with the SETS method. The initial learning used consists of: Syllabus, Lesson Plans (RPP), Student Worksheets, Student Textbooks, and Critical Thinking Skill Tests. The results of learning material are developed with the 4D model, then learning materials are applied in the learning process. The main products are learning materials covering the syllabus, learning material designs, student worksheets, student's textbooks, and test questions for critical thinking skills to be applied in high school physics learning.

Table 1. The criteria of validation.

\begin{tabular}{c|c}
\hline Score & Category \\
\hline 1.00 & Very Invalid \\
2.00 & Invalid \\
3.00 & Valid \\
4.00 & Vey Valid \\
\hline
\end{tabular}

(Nizar, 2018)

\section{Data Analyze}

After the data is collected, a data analysis technique is performed, the researcher tries to describe the results of his research. In the process of data analysis, there are several stages which include normality test, homogeneity test, hypothesis testing, and Normal Gain score. Before learning, the instrument analysis is performed including validity and reskill tests. Data analysis prerequisite test to determine the effect of PBL-SETS learning on students' critical thinking skills in this study:

1) Normality test with the following hypothesis:

$\mathrm{H}_{0}$ : sig $\geq 0.05=$ Data from the population are normally distributed 
$\mathrm{H}_{1}:$ sig $<0.05=$ Data from the population are not normally distributed

2) Homogeneity test with the following hypothesis:

$\mathrm{H}_{0}: \sigma_{1}^{2}=\sigma_{2}^{2}$ (the variance between groups is homogeneous)

$\mathrm{H}_{1}: \sigma_{1}^{2} \neq \sigma_{2}^{2}$ (variance between groups is not homogeneous)

3) Paired sample t-test with the following hypothesis:

$\mathrm{H}_{0}: \mu_{1} \geq \mu_{2}$ (PBL-SETS method does not affect increasing students' critical thinking abilities in physics)

$\mathrm{H}_{1:} \mu_{1}<\mu_{2}$ (PBL-SETS method affects increasing students' critical thinking abilities in physics)

4) N Gain Score

To find out the increase in critical student's skills used the following formula by Hake (2002):

$$
N-\text { gain }=\frac{S_{\text {post }}-S_{\text {pre }}}{S_{\text {maks }}-S_{\text {pre }}}
$$

The gain scores obtained can then be categorized based on Table 2 .

Table 2. N-gain score category.

\begin{tabular}{cc}
\hline Gain Score & Category \\
\hline$(<\mathrm{g}>)<0.3$ & Low \\
\hline $0.3<(<\mathrm{g}>)<0.7$ & Medium \\
\hline$(<\mathrm{g}>)<0.3$ & High \\
\hline
\end{tabular}

(Hake, 2002)

\section{Analysis of Student's Response}

Students' response data are obtained from the questionnaire responses of students after participating in the learning process using PBL with the SETS method. The collect data was processing and interpretation with the following criteria.

Table 3. The criteria for interpretation of the respondent.

\begin{tabular}{c|c}
\hline Score & Category \\
\hline $0-20$ & Very Not Agree \\
$21-40$ & Not Agree \\
$41-60$ & Less Agree \\
$61-80$ & Agree \\
$81-100$ & Vey Agree \\
\hline
\end{tabular}

(Riduwan, 2012)

\section{RESULTS AND DISCUSSION \\ Learning Materials Validation}

The average validity result of learning materials can be seen in Table 4 .

Table 4. The average validity score of learning material achievement.

\begin{tabular}{lcc}
\hline \multicolumn{1}{c}{ Name } & Average of Validity Score & Category \\
\hline Syllabus & 3,84 & Very Valid \\
Lesson Plan (RPP) & 3,50 & Valid \\
Student's Worksheet & 3,86 & Very Valid \\
Student's Textbook & 3,80 & Very Valid \\
Critical Thinking Test & 3,75 & Very Valid \\
\hline
\end{tabular}


Based on the data obtained, it shows that the PBL model with the SETS method tools has a very valid category and it can be used in the learning process. According to Draghicescu (2014) suggests the fact that when using PBL teaching during science lessons, students not only acquire cognitive skills but also a series of instruments (while pursuing one goal) and enable them to expand learning in the long term.

\section{PBL-SETS Learning Achievement}

Table 5. Learning observation results.

\begin{tabular}{ccccccc}
\hline \multirow{2}{*}{ No. } & \multirow{2}{*}{ Meeting } & \multicolumn{4}{c}{ Implementation } & \\
\cline { 3 - 6 } & & \multicolumn{2}{c}{ Yes (\%) } & \multicolumn{2}{c}{ No (\%) } & Category \\
\cline { 3 - 6 } & O1 & O2 & P1 & P2 & \\
\hline 1. & I & 84 & 84 & 16 & 16 & Good \\
2. & II & 91 & 96 & 9 & 4 & Good \\
3. & III & 82 & 88 & 18 & 12 & Good \\
& & 87 & 89 & 13 & 11 & \\
& Average & \multicolumn{2}{c}{87} & & 13 & Good \\
\hline
\end{tabular}

Based on the results of observation, the implementation of learning is in the good category with a percentage of $88.00 \%$, this is under the opinion of Thobroni (2015) that in the learning process, teachers must have a strategy so that the desired goals can be achieved effectively and efficiently. A teacher who uses a certain method is expected to provide fun and satisfaction to students through the implementation of good learning. This is one of the factors in motivating students to be able to use their knowledge to solve a problem at hand.

The problem-based learning (PBL) model is a learning model where the teacher has the role of posing a variety of authentic problems, asking questions, and facilitating investigation and dialogue. PBL helps students to develop critical thinking skills and problem-solving skills, learn the roles of adults and become independent learners. Students as research subjects are directly involved with the problem and challenged to learn to solve the problem, the problem-solving process is closely related to students' skill to think critically. Critical thinking is a general term given to a variety of cognitive skills and intellectual characters that are needed effectively to identify, analyze and evaluate arguments, claim truths to find and overcome personal prejudices, can formulate and present convincing reasons to support conclusions, and make decisions smart about what to believe and what to do (Bassham, et al., 2018). The aspect of knowledge becomes the main supporting factor in critical thinking skills, because problem-solving related to higher thinking requires a mature understanding of concepts, besides that perceptions arise from the students' learning experiences. The teacher becomes the developer facilitator of the students' knowledge, in this case, the perception that has been built in the minds of the students must be broadened.

\section{The Result of Critical Thinking Students}

Based on the characteristics of physics science learning that requires students to have high analytical and evaluation skills in solving each problem and from the opinions of Facione (2015) about critical thinking indicators, the researchers propose indicators that 
are used to describe students' critical thinking abilities, namely the skill interpretation, analysis, inference, and evaluation.

Table 6. Critical thinking indicators used in research.

\begin{tabular}{|c|c|c|}
\hline No. & Indicator of critical thinking & Aspects \\
\hline 1. & Interpretation skill & Observe, understand, underline and explain a material \\
\hline 2. & Analysis & Identify, recognize and solve problems \\
\hline 3. & Inference skill & $\begin{array}{l}\text { Draw reasonable conclusions by considering relevant } \\
\text { information }\end{array}$ \\
\hline 4. & Evaluation skill & $\begin{array}{l}\text { Assess and make appropriate assessment solutions to } \\
\text { problems }\end{array}$ \\
\hline 5. & Explanation & Explain, elaborate, communicate \\
\hline
\end{tabular}

To find out the criteria or levels of students' critical thinking skills, a post-test score can be used as a reference with the following category guidelines:

Table 7. Score category.

\begin{tabular}{cc}
\hline \multicolumn{1}{c}{ Score Post Test } & Category \\
\hline $\mathbf{8 1 , 2 5 -} \leq \mathbf{1 0 0}$ & Very Critical \\
$\mathbf{8} \mathbf{6 2 , 5 0 -} \leq \mathbf{8 1 , 2 5}$ & Critical \\
$\mathbf{> 4 3 , 7 5}-\mathbf{6 2 , 5 0}$ & Less Critical \\
$\mathbf{>} \mathbf{2 5 , 0 0 -} \leq \mathbf{4 3 , 7 5}$ & Very Less Critical \\
\hline
\end{tabular}

Based on research conducted, obtained the following critical thinking abilities of students. Critical thinking test results category The following is a table categorizing the results of the pretest and posttest critical thinking skills of students.

Table 8. Pretest and posttest value categories.

\begin{tabular}{ccc}
\hline Category & Description & Amount \\
\hline $80.0-100$ & Very good & 0 \\
$65-79,9$ & Good & 0 \\
$55-64,9$ & Enough & 3 \\
$40-54,9$ & Less & 17 \\
$0-39,9$ & Very less & 13 \\
\hline
\end{tabular}

Based on the results of the pretest and posttest results showed that after being given learning the students' grades improved, ranging from very poor categories to good and very good categories. This study, to train students in improving critical thinking skills for each indicator ranging from $42 \%$ to $64 \%$. The result of the test in every indicator of critical thinking skill can be seen in Figure 1. 


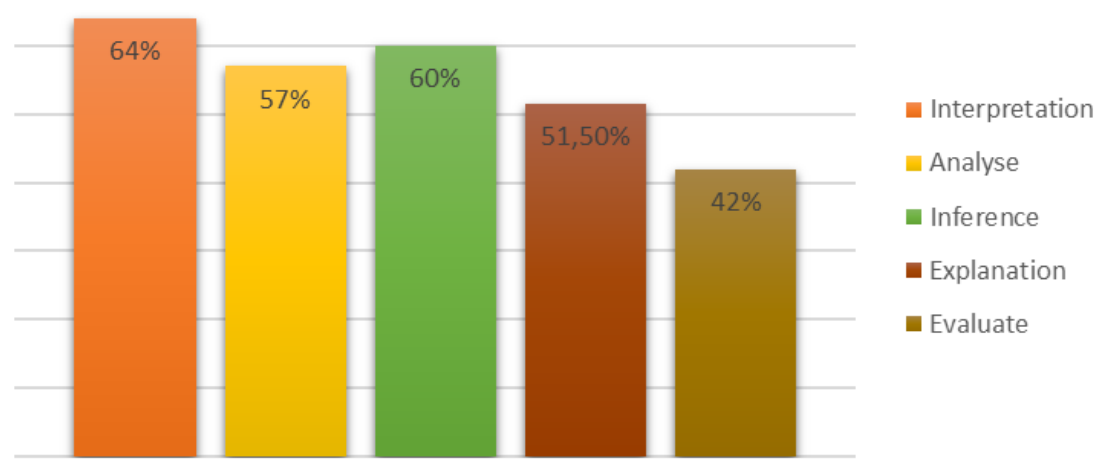

Figure 1. Diagram of critical thinking in each indicator result.

The results of data analysis of critical thinking skills of students showed the lowest indicator, namely evaluating skills by $42 \%$, with a low category. The low indicators evaluate, due to the lack of students' skills to assess the arguments of a problem, and students are accustomed to only getting information from the teacher. This is consistent with the results of observations that have been made that students are not accustomed to assessing the quality of the argument of questions that have been made based on problems and students are not accustomed to checking and sorting out the questions that have been made in the discussion.

\section{Hypothesis Analysis of Influence Based on Hypothesis Testing Results}

a. Normality Test of Experiment Class

Table 9. Normality data.

\begin{tabular}{lcccc}
\hline & Factor & \multicolumn{3}{c}{ Kolmogorov-Smirnov } \\
& & Statistic & df & Sig. \\
\hline Critical thinking skill test & pretest &, 15 & 33 &, 080 \\
& posttest &, 14 & 33 &, 104
\end{tabular}

a. Lilliefors Significance Correction

Based on the results of statistical calculations obtained a significance value of $0.77>0.05$ which means the data are normal.

b. Homogeneity test

Table 10. Homogeneity data result.

\begin{tabular}{llcc}
\hline & & $\begin{array}{c}\text { Levene } \\
\text { Statistic }\end{array}$ & Sig. \\
\hline Tes & Based on Mean & 3,18 &, 079 \\
$\mathrm{t}$ & Based on Median & 2,35 &, 130 \\
\hline
\end{tabular}

Based on the results of statistical calculations obtained a significance value of $0.79>0.05$ which means the data are homogeneous. 
c. Paired sample t-test

Table 11. T-test result.

\begin{tabular}{cccccccc}
\hline & \multicolumn{9}{c}{ Paired differences } & t & df & Sig. (2-t) \\
\cline { 3 - 8 } & Mean & $\begin{array}{c}\text { Std. } \\
\text { dev }\end{array}$ & $\begin{array}{c}\text { Std. Er } \\
\text { mean }\end{array}$ & & & \\
\hline Pair 1 & Pre Post & -33 & 8 & 1,5 & $-21,9$ & 32 &, 000 \\
\hline
\end{tabular}

The results of statistical calculations show $t_{\text {calculate }}-21,9<t_{\text {table }} 1.69$ which means that $\mathrm{H}_{0}$ is rejected and $\mathrm{H}_{1}$ is accepted, meaning that there is an influence of PBL with SETS method on increasing students' critical thinking skills. Research conducted by Peter (2012) provides results about the essence of critical thinking to solve problems showing that instructional strategies improve students' critical thinking skills and involve students in the learning process rather than controlling lectures and rote memorization. Based on the data obtained, it can be seen that the level of critical thinking skill of students increases after receiving learning, meaning that the learning applied influences students' abilities. the development of the critical thinking assessment instrument approached SETS effectively measures students 'critical thinking skills because the results of students' critical thinking skills can be relatively distinguished and objectively measured.

PBL learning is supported by several learning theories, one of which is constructivism. The theory of constructivism is a learning philosophy based on the premise that by reflecting on the experience, one can build or construct our understanding of knowledge about the world in which we live. so that it can be said constructivism learning is learning that emphasizes the independence of students to be able to build knowledge through interaction with the environment, so that teachers do not just give knowledge to students, but students must build their knowledge in the thought process. John Dewey is one of the constructive figures said that outlines the concept of inquiry described in the stages of reflective thinking. which includes: (1) Individuals feel a problem; (2) Individuals localize and limit understanding of the problem; (3) Individuals find the relationship of the problem and formulate a hypothesis solving based on the knowledge they have; (4) Individuals evaluate the hypothesis that is determined; (5) Individuals apply the predetermined and chosen way of solving problems. The theory is following PBL learning with sets, where students learn based on a problem that is integrated with four aspects in the SETS method. Based on research conducted by Nugrhoho (2011) Learning physics with SETS can make students understand competence, not only mastering physics in the field of knowledge and skills but also care for the environment, technology, and social society. The process of habituation of attitudes changes from the beginning of learning to the compilation of students changing attitudes according to indicators to become habits. The formation of attitudes that occur at some time to change personal attitudes starting from dissatisfaction, followed by logical and rational thinking, dare to take risks. and responsibility until completion. the results of the study show the positive effect of applying sets-based learning. in this study, learning is done by combining the presentation of problems through the integrated PBL model with SETS aspects. so students can think logically and complexly in learning physics by the inclusion of phenomena in daily life 
The value of increasing critical thinking skills

Based on the research, the category of improvement students' critical thinking skills is increasing both in the low, medium, and high improvement categories, after the treatment using problem-based learning with the SETS method. After learning activities, it was obtained that the N-Gain increased the average value of students' is 0.7 it means the improvement is on the medium category with learning under the syntax in PBL combined with the integration of science on the elements of the technological environment, and social (SETS). The result of this research is Normality Gain Score in the low category by $3 \%$, in the medium category by $67 \%$, and the high category by $30 \%$. Students are active in learning to interpret and analyze the problems presented to express opinions. This is in line with the opinion of Chantaranima \& Yuenyong (2014) explaining that learning that emphasizes critical thinking behavior can be seen during the learning process, discussion, presentation, and completion of student assignments.

\section{Analyze of Student Learning Responses}

The student's response data related to learning with the implementation of problembased learning with the SETS method to improve critical thinking students. It can be known by the result of the questionnaire filled out by students after the learning process. The questionnaire includes twenty questions that must be answered honestly by students. The result of student's responses can be seen in figure 2 below.

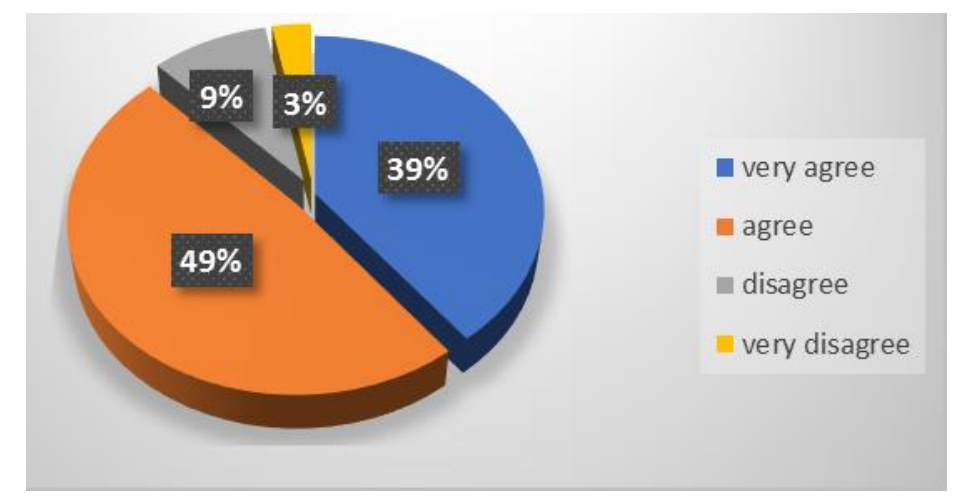

Figure 2. The percentage of the student's response.

Based on the data above, the students' responses were categorized as good. According to Hidayati (2013) Response is an impression or reaction after we observe the activity of sensing, evaluating, the object of the form of attitude towards the object can be in the form of a negative or positive attitude. When students feel comfortable with learning models implemented in the classroom, students will give positive responses, for example, in an orderly and active manner in learning, but if the response given is negative towards learning, students do not pay good attention in learning which certainly can affect test results the student. In the learning that has been done, most students are enthusiastic and give positive responses, but some students give negative responses to learning, it is known through a questionnaire filled directly by students.

The reality in the class when the first meeting with students who will be treated, students still look confused with learning that is still considered new by them, but after the teacher explains what is SETS accompanied by the SETS method, then the teacher 
gives problems that exist in daily life related to the material dynamic fluid, students begin to understand the meaning of PBL with SETS learning when the discussion has lasted several minutes. From the observers' observations, it is known that the PBL syntax is well implemented and there are no missing stages. So it can be concluded that the experimental class that is subject to the PBL-SETS learning applies the actual learning although there are some shortcomings, namely that students cannot independently construct concepts during the discussion, for that they need a little help from the teacher. PBL-SETS learning seeks to bring students to have the skill to see things in an integrated way by linking the four SETS elements so that a deeper understanding can be obtained.

Through PBL model-based learning at the first meeting students do the practicum by designing a simple barometer, and at the second meeting, students make a simple replica of the reservoir. In both replica-making projects are solutions to problems presented by the teacher that encourage students to analyze problems, find solutions, design tools as problem solutions to present the results of the experiment. Through learning activities involving various elements and problems related to students 'lives, students gain a deeper understanding, the results of students' critical thinking skills tests will also improve. Through the context of learning based on problems in creativity that are also correlated with critical thinking skills, obtained a significant PBL on the skill of students to solve problems more carefully. The problem-based approach is included in philosophy, PBL learning is based on developing teaching strategies as a useful approach; teaching strategies, methods, and techniques are distinguished in creativity and critical thinking skills. so that PBL learning combined with the sets method is the right choice to apply in developing students' critical thinking skills.

Through problem-based learning, students are encouraged to develop the skill to interpret, inference, analyze, evaluate, and explore it through classroom presentations related to practicums. students also arrange posters as one of the assignments to show the application of dynamic fluid concepts that they have learned. the test results that have been given by students have the highest increase in the skill of interpretation, then sequentially the skill to explore, analyze, inference, but the results show that the difficulty in the domain of skill to evaluate. based on the observations of researchers, this happens because students are not accustomed to assessing and correcting what has been done and written in the report. So students have difficulty developing evaluation skills compared to other domains. Based on Pebriana's research (2017) there is an increase in critical thinking learning in students who learn to use problem-based learning models higher than students who study using conventional learning. This shows that problem-based learning is a strategy implemented to develop students' critical thinking skills. Learning begins with exposing students to real-life problems (authentic) or simulation problems, so students are required to think critically and at the same time use students as problem-solving, so students develop in developing their critical thinking skills. so according to Salido (2018) in an increasingly advanced era, curriculum renewal in Indonesia is intended so that students increasingly have optimal development in the types of skills including communication, collaboration, critical thinking and problem solving, and creativity and innovation.

Based on research conducted by Lukitasari (2019) before the blended-PBL application students are less able to understand and identify terms, consider definitions are unable to provide further explanation in detail. Besides, students also have difficulty in 
concluding a discussion while this is one indicator of critical thinking, namely inference, so students have difficulty applying concepts to different problem situations. But after applying blended PBL students can develop the domain of critical thinking skills, so that they can provide an explanation, build basic skills, provide further explanation, make problem-solving and draw appropriate conclusions. The innovation in learning activities is expected to prepare and support the learning process following the needs of the $21^{\text {st }}$ Century.

PBL in presenting cases of effective educational experiences for school teachers in vocational. This was also shown by research conducted by Chiang (2016) on vocational secondary students. This study explores the effect of PBL on student motivation and skill to solve problems. In addition to learning outcomes, the results of the study show that PBL has a positive influence on student motivation. This encourages vocational high school teachers that their students have the potential to enjoy learning if the teaching strategy is more PBL style.

In applying a learning model the teacher must know that students have at least a little knowledge of the basic principles of scientific thought, the skill to expand and develop these ideas in various subject areas because that will further encourage and promote these skills Schmaltz (2017). For example, when discussing whether changes are found on a barometer student worksheet, a teacher can add a brief discussion about why some people reject the science of weather change by linking this back to information that students will be familiar with from their scientific thinking courses. In matters of climate change, many students may have heard in popular political or cultural debates that global warming trends are not real.

The use of problem situations in this study promotes better critical thinking in problem-solving among students. This can lead to better motivation and thinking mechanism for students to organize their knowledge Belecina (2018). Problem situations that require students to demonstrate their skill of knowledge and declarative procedures of valid knowledge in assessing the results of critical thinking. Moreover, this problem situation develops students' skills to be more reflective and metacognitive, especially when analyzing problems.

According to Masek (2011) it was concluded that 1) the specific process in PBL theoretically supports the development of students 'critical thinking under the applied learning design, 2) empirical evidence in general is not convincing in explaining the effect of PBL on students' critical thinking abilities, especially studies outside in the medical field, 3) PBL requires long-term learning to continue to be able to develop students' critical thinking skills, 4) some factors may also influence the relationship of PBL and critical thinking as well as those of age, gender, academic achievement, and educational background, which require further research. The implication is that, PBL curriculum must be carefully designed and pay attention to which aspects contribute to PBL effectiveness. This is the role of the teacher as a student facilitator in learning, especially in triggering students' meta-cognitive thinking. With all this carefully considered, PBL can be successfully applied according to theories that have been recognized for its effectiveness.

\section{CONCLUSIONS}

The implementation of learning was carried out in a good category in each meeting. Increasing the critical thinking skills of physics of dynamic fluid material is significant. 
That means learning has a positive effect on an increase in students' critical thinking skills. the response of students to learning on average has a good to very good category, so the learning undertaken gets a positive response from students. Problem-based learning with the SETS method is expected to be able to make students more actively in the process of gaining knowledge directly so that students can develop their critical thinking skills. Students can more easily understand the concept of fluid dynamics in physics to solve problems and getting higher critical thinking skill. So for the readers who want to conduct relevant research to this research, the effectiveness of learning can be reviewed from other aspects. Suggestions for further research teachers need to pay attention to the difficulties faced by students so that students do not make the same mistakes when solving problems, pay attention to the selection of more efficient learning media, further research needs to be done to improve students' critical thinking skills by using problems by linking elements of SETS which involves all indicators of critical thinking skills.

\section{REFERENCES}

Akcay, B., \& Akcay, H. (2015). Effectiveness of science-technology-society (STS) instruction on student understanding of the nature of science and attitudes toward science. International Journal of Education in Mathematics, Science and Technology, 3(1), 37-45.

Bassham, G., Irwin, W., Nardone, H., \& Wallace, J.M. (2018). Critical thinking: A student's introduction. New York: The McGraw-Hill Companies.

Belecina, R.R., \& Ocampo Jr, J.M. (2018). Effecting change on students' critical thinking in problem solving. Educare, 10(2), 109-118.

Chantaranima, T., \& Yuenyong, C. (2014). The outcomes of teaching and learning about sound based on science technology and society (STS) Approach. Procedia-Social and Behavioral Sciences, 116, 2286-2292.

Chiang, C.L., \& Lee, H. (2016). The effect of project-based learning on learning motivation and problem-solving skill of vocational high school students. International Journal of Information and Education Technology, 6(9), 709-712.

Drăghicescu, L.M., Petrescu, A.M., Cristea, G.C., Gorghiu, L.M., \& Gorghiu, G. (2014). Application of problem-based learning strategy in science lessons-Examples of good practice. Procedia-Social and Behavioral Sciences, 149, 297-301.

Facione, P.A. (2015). Critical thinking: What it is and why it counts. Insight Assessment, 20(1), 1-23.

Hake, R.R. (2002). Relationship of individual student normalized learning gains in mechanics with gender, high-school physics, and pretest scores on mathematics and spatial visualization. Boise, Idaho: Physics Education Research Conference.

Hidayati, N. (2013). Respon guru dan siswa terhadap pembelajaran permainan bolavoli yang dilakukan dengan pendekatan modifikasi (Pada Siswa Kelas V SDN Wateswinangun I Sambeng-Lamongan). Jurnal Pendidikan Olahraga dan Kesehatan, 1(1), 104-106.

Hove, G. (2011). Developing critical thinking skills in the high school English classroom (Unpublished master's thesis). University of Wisconsin-Stout, Menominee, WI.

Maimunah, M. (2017). Retracted article: The use of science environment technology and society (SETS) Learning model for enhancing the critical thinking skills and scientific attitudes. Jurnal Penelitian dan Pembelajaran IPA, 3(1), 65-73. 
Masek, A., \& Yamin, S. (2011). The effect of problem based learning on critical thinking skill: a theoretical and empirical review. International Review of Social Sciences and Humanities, 2(1), 215-221.

Nizar, M. (2018). Pengembangan Perangkat Pembelajaran Model Inkuiri Terbimbing untuk Meningkatkan Keterampilan Berpikir Kreatif Siswa SMA Negeri 1 Balongoanggang. Surabaya: Unesa.

Lukitasari, M., Purnamasari, I., Utami, S., \& Sukri, A. (2019). Blended-Problem-Based Learning: How its impact on students' critical thinking skills? JPBI (Jurnal Pendidikan Biologi Indonesia), 5(3), 425-434.

Pebriana, R., \& Disman, D. (2017). Effect of problem based learning to critical thinking skills elementary school students in social studies. Primary Edu-Journal of Primary Education, 1(1), 109-118.

Peter, E.E. (2012). Critical thinking: Essence for teaching mathematics and mathematics problem solving skills. African Journal of Mathematics and Computer Science Research, 5(3), 39-43.

Poedjiadi, A. (2010). Sains teknologi masyarakat model pembelajaran kontekstual bermuatan nilai. Bandung: Remaja Rosdakarya.

Priyadi, R., Mustajab, A., Tatsar, M.Z., \& Kusairi, S. (2018). Analisis kemampuan berpikir kritis siswa SMA kelas X MIPA dalam pembelajaran fisika. JPFT (Jurnal Pendidikan Fisika Tadulako Online), 6(1), 53-55.

Riduwan. (2012). Pengantar statistika untuk penelitian pendidikan, sosial, ekonomi, komunikasi dan bisnis. Bandung: Alfabeta.

Riwu, R., Budiyasa, I.W., \& Rai, I.G.A. (2018). Penerapan pendekatan SETS (Science, Environment, Technology, and Society) untuk meningkatkan hasil belajar biologi siswa. Emasains: Jurnal Edukasi Matematika dan Sains, 7(2), 162-16

Salido, A., \& Dasari, D. (2018). The analysis of students' reflective thinking skill viewed by students' mathematical skill at senior high school. In International Conference on Mathematics and Science Education.

Schmaltz, R.M., Jansen, E., \& Wenckowski, N. (2017). Redefining critical thinking: Teaching students to think like scientists. Frontiers in Psychology, 8, 459-465.

Taylor, J. (2012). Philosophical teaching will get students thinking for themselves again. The Guardian. Retrieved from https://tinyurl. com/ybsn4de6.

Thobroni, M. 2015. Belajar dan Pembelajaran Teori dan Praktik. Jakarta: Ar-Ruz Media.

Usmeldi, U., Amini, R., \& Trisna, S. (2017). The development of research-based learning model with science, environment, technology, and society approaches to improve critical thinking of students. Jurnal Pendidikan IPA Indonesia, 6(2), 318-325. 
*Devy Alvionita, M.Pd. (Corresponding Author)

Universitas Negeri Surabaya,

Postgraduate School,

Science Education Study Program

Continuing Program Development, Jl. Unesa Lidah Wetan, Surabaya, Indonesia

Email: $\underline{\text { devyalvionita.18039@mhs.unesa.ac.id }}$

\section{Prof. Dr. Prabowo, M.Pd}

Universitas Negeri Surabaya,

Science Education Study Program

Continuing Program Development, Jl. Unesa Lidah Wetan, Surabaya, Indonesia

Email: prabowo@unesa.ac.id

Dr. Z.A. Imam Supardi, M.Si

Universitas Negeri Surabaya,

Science Education Study Program

Continuing Program Development, Jl. Unesa Lidah Wetan, Surabaya, Indonesia

Email: zsupardi@gmail.com 